\title{
Orbicular magnetitite from the Catalão I phoscorite-carbonatite complex
}

\author{
M. Palmieri ${ }^{1,2}$, G. S. B. Pereira ${ }^{2}$, J. A. Brod ${ }^{2}$, T. C. Junqueira-Brod ${ }^{2}$, I. A. Petrinovic ${ }^{3}$ and \\ A. J. D. Ferrari ${ }^{4}$ \\ ${ }^{I}$ Anglo American Brasil Ltda, Brazil \\ ${ }^{2}$ Universidade de Brasília, Brazil \\ ${ }^{3}$ Universidad Nacional de Salta, Argentina \\ ${ }^{4}$ Copebrás Ltda., Brazil \\ (matheus.palmieri@angloamerican.com.br/Phone: +55 613307 2873)
}

\section{Introduction}

The Catalão I phoscorite-carbonatite complex is part of the Late-Cretaceous Alto Paranaíba Igneous Province (APIP), which also includes other major plutonic, carbonatite-bearing complexes, such as Tapira, Araxá, Salitre I and II, Serra Negra, and Catalão II (Fig. 1).

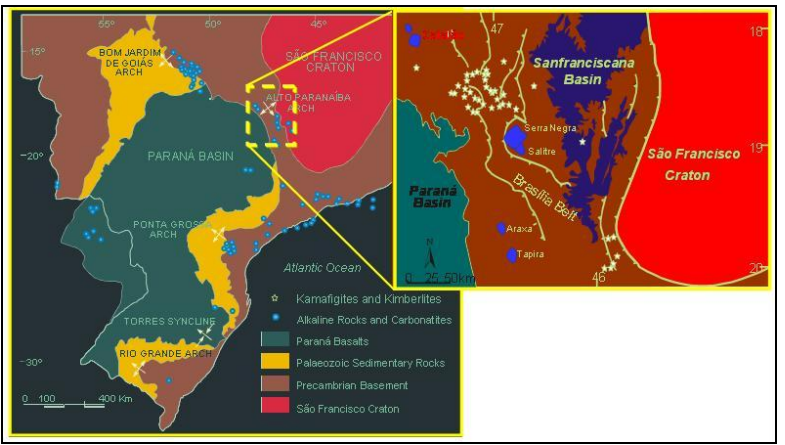

Fig. 1 Alkaline-carbonatite provinces at the borders of the Paraná Basin in Brazil and Paraguay. Inset: Alto Paranaíba Igneous Province (after Gibson et al., 1995).

It is a roughly circular, $5.5 \times 6 \mathrm{~km}$ dome structure composed of ultramafic, carbonatitic and phoscoritic rocks. The complex contains unexploited deposits of REE, Ti, and vermiculite, and is currently mined for $\mathrm{Nb}$ and phosphate. Fresh rock outcrops occurring in the Copebrás phosphate mine (Anglo American Group), in the NW portion of the dome, allowed the distinction of three main petrogenetic series. The phoscorite series comprises phoscorites, nelsonites, apatitites, and magnetitites; the carbonatite series consists of dolomite carbonatite and calcite carbonatite; the bebedourite series is represented by ultramafic silicate rocks almost entirely converted to metasomatic phlogopitites. Except for the phlogopitites, all the other rocks occur as stockworks of dykes of variable thickness which crosscut each other and the phlogopitite.

Liquid immiscibility textures recognized in the fresh rock comprise apatite aggregates within carbonatites, carbonate globules in silicate rocks, and orbicular structures. The aim of this work is to characterize the orbicular structures using petrography, mineral chemistry, and $\mathrm{C}$ and $\mathrm{O}$ stable isotopes.

\section{Petrography}

The orbicular structures are abundant in a one-meter thick carbonate-phlogopite magnetitite dyke emplaced in carbonatite. The orbicules are subcentimetric to centimetric, spheroidal to elipsoidal, and well rounded, with a few broken angular individuals. They are concentrically layered, commonly consisting of two or three alternating layers dominated either by magnetite or by tetra-ferriphlogopite. Olivine, carbonate and ilmenite are present in subordinate amounts. Individuals with a larger number of layers (up to five) are relatively rare. In some cases the structure may be incomplete, forming a crescent shape, which suggests that the original orbicule was fragmented during turbulent flow of the magma.

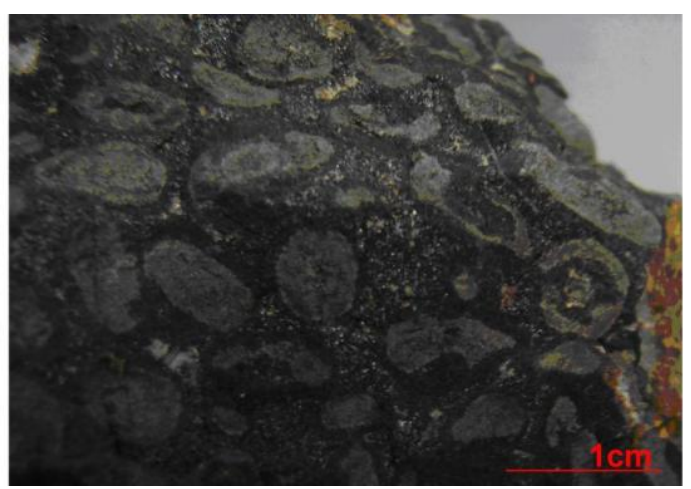

Fig. 2: General aspect of the Catalão I orbicular magnetitite in hand-sample.

The orbicules are set in a grounmass varying in composition from phlogopite magnetitite to carbonate magnetitite. Magnetite occurs as fine-grained (up to 0.4 $\mathrm{mm}$ ) crystals or aggregates. Tetraferri-phlogopite occurs as euhedral to subhedral crystals, some of which display optical and compositional zoning, with cores of more Al-rich phlogopite. Carbonate occurs as an interstitial material of forming small, irregularly shaped 
pockets, suggesting late-stage seggregation of carbonatite during crystallization of the groundmass.

\section{Mineral Chemistry}

The composition of the main mineral phases was determined using a CAMECA SX-50 electron microprobe at the University of Brasília.

Magnetite is $\mathrm{Al}$ - and $\mathrm{Cr}$-poor (up to 0.1 wt.\% $\mathrm{Al}_{2} \mathrm{O}_{3}$, 0.08 wt. $\% \mathrm{Cr}_{2} \mathrm{O}_{3}$ ), and contains up to 5.7 wt.\% $\mathrm{TiO}_{2}$, 1.2 wt. $\% \mathrm{MnO}$, and 8.24 wt.\% $\mathrm{MgO}$. This composition is consistent with magnetite from other APIP phoscorites and carbonatites, but higher in $\mathrm{MgO}$ than typical magnetite from bebedourites (Barbosa et al., 2008a, Brod et al., 2005). Ulvöspinel exsolutions are locally observed in magnetite crystals, and contain up to 1.92 wt.\% $\mathrm{MgO}, 0.97$ wt. $\% \mathrm{Nb}_{2} \mathrm{O}_{5}$, and 5.21 wt.\% $\mathrm{MnO}$. Magnetite also contain small inclusions of a member of the geikielite-ilmenite series (64-78\% geikielite, $2.4-4.4 \% \mathrm{MnO}$ )

Carbonate is dominantly dolomite, containing 1.4-2.3 wt. $\% \mathrm{SrCO}_{3}$ and up to 1.52 wt. $\% \mathrm{FeCO}_{3}$ and 0.54 wt. $\%$ $\mathrm{MnCO}_{3}$. Rare calcite crystals contain ca. 2.8 wt.\% $\mathrm{SrCO}_{3}$. The composition of the carbonates, particularly the high $\mathrm{Sr}$ content indicates an igneous origin.

Fine- to very fine-grained euhedrical to subedrical tetra-ferriphlogopite crystals show 0.57-3.3 wt.\% $\mathrm{Al}_{2} \mathrm{O}_{3}$, rarely exibiting a more Al-rich (ca. 9 wt. \% $\mathrm{Al}_{2} \mathrm{O}_{3}$ ) core (Fig. 3). $\mathrm{TiO}_{2}$ (up to 0.09 wt.\%) and $\mathrm{BaO}$ (up to 0.17 wt.\%) are low.

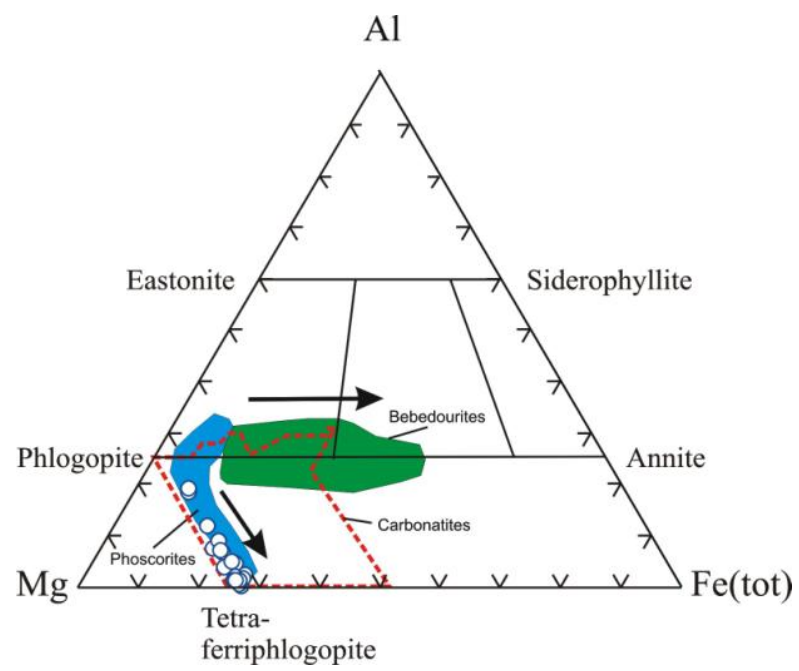

Fig 3. Composition of phlogopite from the Catalão I orbicular magnetitite, compared with other rock-types from the APIP (Brod et al., 2001, Barbosa et al., 2008a,b, Cordeiro et al., 2008)

Figure 3 illustrates the composition of the studied phlogopite, in comparison with those of other APIP complexes (Brod et al., 2001, Barbosa et al. 2008a,b, Cordeiro, 2008). The data cover the whole range of the phlogopite-tetra-ferriphlogopite series. The composition of phlogopite from the orbicular rock is very close to that of phlogopite in APIP phoscorite-series rocks, supporting the nelsoniticmagnetitic afinity of the studied samples.

Olivine composition is close to $\mathrm{Fo}_{96}$. It contains up to 0.44 wt. $\% \mathrm{MnO}$ and very little $\mathrm{Ni}$ (average 0.01, locally reaching up to $0.06 \mathrm{wt} \% \mathrm{NiO}$ ), which is consistent with a carbonatite or phoscorite affinity (e.g. Gaspar et al., 1998).

Ilmenite contains up to 0.38 wt. $\% \mathrm{Nb}_{2} \mathrm{O}_{5}, 21.00$ wt.\% $\mathrm{MgO}$, and 2.65 wt.\% MnO. Figure 4 compares the ilmenite of the orbicular magnetitite with that of other alkaline rocks. The ilmenites studied here plot near the $\mathrm{Mg}$-rich end of the carbonatite ilmenite field.

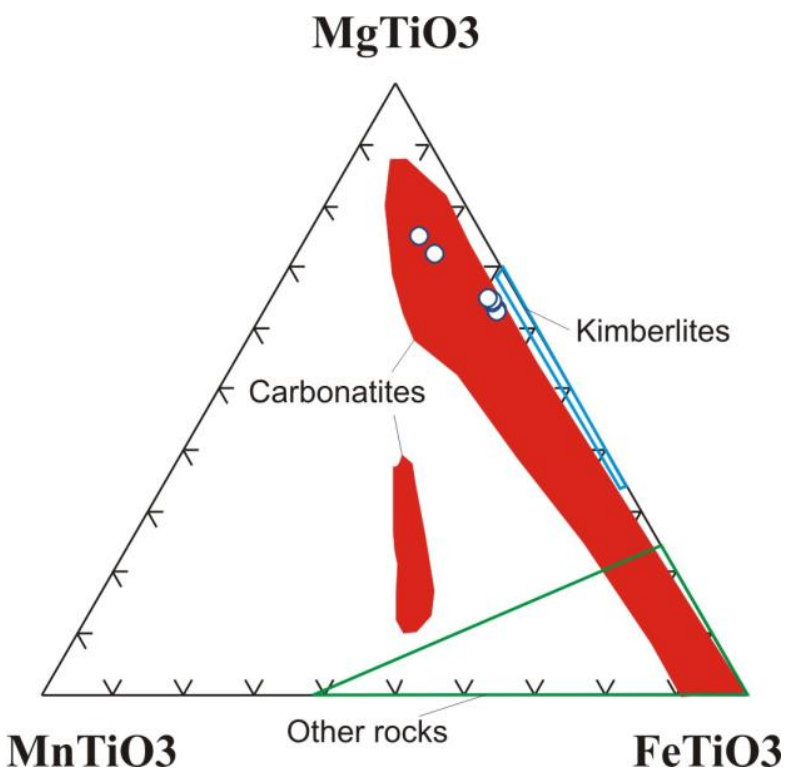

Fig. 4 Comparison of the ilmenite in the orbicular magnetitite with ilmenite in other alkaline rocks (Gaspar and Wyllie, 1987).

\section{$\mathrm{C}$ and $\mathrm{O}$ Isotopes}

Carbon and Oxygen stable isotope ratios were determined using a Gas Bench II System connected to a Delta V Advantage gas-source mass spectrometer at the University of Brasília.

The results for three carbonate samples extracted from the carbonate pockets in the magnetitite groundmass yielded $\delta^{13} C_{\mathrm{PDB}}$ values of $-6,18,-6,26$ and $-6,25 \%$. These figures are within the mantle carbonate composition range $\left(\delta^{13} \mathrm{C}_{\mathrm{PDB}} \approx-4\right.$ a $-8 \%$ ) indicating a magmatic origin for the orbicular magnetitite. Moreover, they indicate that the analysed rock was not affected by $\mathrm{CO}_{2}$-rich (i.e. carbonatititc) metasomatism, which is a particularly intense process at Catalão I. Therefore, we interpret the orbicular magnetitite dyke as representative of a late magmatic phase in the complex evolution.

Oxygen isotope analyses yielded $\delta^{18} \mathrm{O}$ values of 9,34 , 9,64 , and $11,6 \%$, also within or close the mantle carbonate composition (ca. 5 to $10 \%$ ). The slightly 
high $\delta^{18} \mathrm{O}$ values may indicate influence of interaction with $\mathrm{H}_{2} \mathrm{O}$-rich fluids (Santos and Clayton, 1995).

\section{X-ray difratometry}

Whole rock X-ray difractometry confirms the mineralogy described in petrography and shows that dolomite is the dominant carbonate both in the groundmass and in the carbonate pockets, with by little amounts of calcite in the latter. (Figs. 5 and 6).

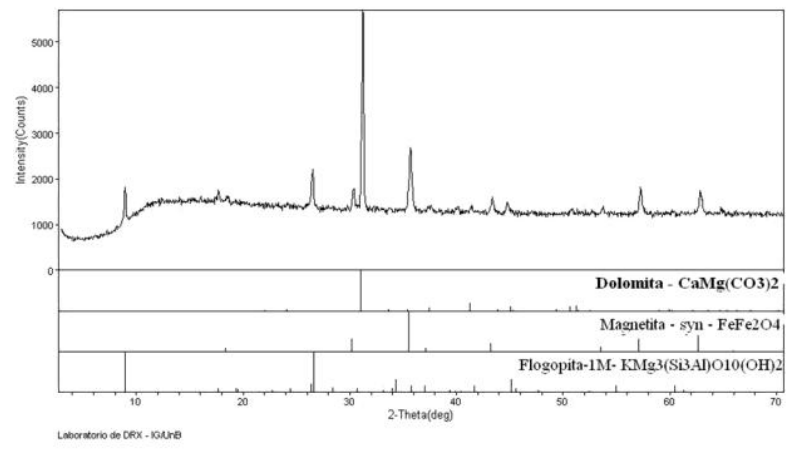

Fig. 5 Whole rock x-ray difractometry analysis of the orbicular magnetitite

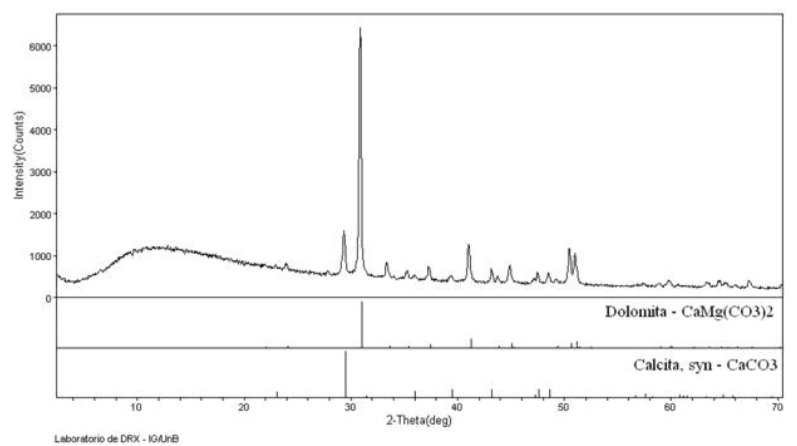

Fig. 6 X-ray difractometry analysis of the carbonate pockets.

\section{Discussion and conclusions}

Petrographic and field evidence indicate that the Catalão I orbicular magnetitite is a late-stage dyke of an extremely magnetite-rich magma intruding carbonatites at the Catalão I complex.

The chemical composition of key mineral phases, such as $\mathrm{Sr}$-rich carbonate, $\mathrm{Mg}$-rich magnetite, high- $\mathrm{Nb}$ and high-Mn ilmenite, tetra-ferriphlogopite, and low-Ni, high-Mn olivine indicate a strong affinity of the studied rock with magmas of the phoscorite series, consistent with other phoscorites and nelsonites occurring in the complex. Carbon and oxygen isotopes in dolomite yielded values that are within or near the range of mantle carbonate isotopic compositions, adding further support to a magmatic, rather than metasomatic origin for the orbicules. Local deformation of the spherical shapes, eccentric cores and incomplete orbicular structures may be a result of fragmentation of the orbicules during turbulent flow within the dyke or in the magma chamber.

Orbicular structures have been often interpreted as a product of liquid immiscibility in carbonate-rich systems (e.g. Lapin and Vartiainen, 1982; Haggerty and Fung, 2006). Field, petrographic, and chemical evidence from the APIP alkaline-carbonatite complexes testify to the importance of liquid immiscibility in the petrogenesis of these rocks. The evidence presented here is consistent with a liquid immiscibility origin for the Catalão I orbicular magnetitite.

\section{Acknowledgements}

The authors are grateful to University of Brasilia (UnB), Anglo American Plc, Copebrás Ltda., and the Brazilian agencies CNPq and CAPES.

\section{References}

Barbosa, E.S.R., Brod, J.A., Junqueira-Brod, T.C., Dantas, E.L. 2008a. Bebedourite, a key rock type in the Alto Paranaíba kamafugite-carbonatitephoscorite association: the case of the Salitre Complex, Central Brazil. In preparation.

Barbosa, E.S.R., Brod, J.A., Junqueira-Brod, T.C. 2008b. Mineralogy and petrology of phoscorites from the Salitre alkaline complex, Minas Gerais State, Brazil. In preparation

Brod J.A., Gaspar J.C., Araújo D.P., Gibson S.A., Thompson R.N., Junqueira-Brod T.C. 2001. Phlogopite and tetra-ferriflogopite from Brazilian carbonatite complexes: petrogenetic constraints and implications for mineral-chemistry systematics. Journal of Asian Earth Sciences, 19, 265-296.

Cordeiro P.F.O., Brod J.A., Gaspar J.C. 2008 - Mineral chemistry and petrology of phoscorite-series rocks (magnetite, apatite and Mg-silicates) from the Catalão I Carbonatite Complex, Goiás State, Central Brazil. In preparation.

Gaspar J.C., Araújo D.P., Melo, M.V.L.C. 1998. Olivine in carbonatitic and silicate rocks in carbonatite complexes. 7th International Kimberlite Conference, Extended Abstracts, 239-241.

Gaspar, J.C., Wyllie, P.J. 1983. Ilmenite (high Mg, Mn, $\mathrm{Nb}$ ) in the carbonatites from the Jacupiranga Complex, Brazil. American Mineralogist, 68, 960971.

Haggerty S.E, Fung A.A. 2006. Orbicular oxides in carbonatitic kimberlites. American Mineralogist, 91, 1461-1472.

Lapin A.V., Vartiainen H. 1982. Orbicular and spherulitic carbonatites from Sokli and Vuorijärvi. Lithos, 16, 53-60

Santos R.V., Clayton R.N. 1995. Variations of oxigen and carbon isotopes in carbonatites: A study of Brazilian alkaline complexes. Geochimica et Cosmochimica Acta, 59, 1339-1352. 